\title{
KAJIAN PENGARUH KEKUASAAN PEMERINTAH ERA POSKOLONIALTERHADAP ARSITEKTUR DI MEDAN
}

\author{
Nadia Winny Silaban ${ }^{1}$, Julyana L. F. Nainggolan², Imam Faisal Pane ${ }^{3}$ \\ Departemen Arsitektur Fakultas Teknik Universitas Sumatera Utara \\ Jl. Perpustakaan St. J07 Building, Medan, 20155, Indonesia \\ *Email: ${ }^{1}$ nadiawinnys@gmail.com, ${ }^{2}$ julyana_leisa@gmail.com, ${ }^{3}$ imamfpane@gmail.com
}

\begin{abstract}
ABSTRAK
Sistem politik dan kekuasaan ikut mempengaruhi ekspresi arsitektur satu lingkungan binaan. Pada era poskolonial, sistem politik suatu negara yang pernah mengalami kolonialisme Eropa harus mampu mengambil keputusan dan membangun sistem pemerintahannya sendiri setelah sebelumnya sistem pemerintahan, politik, bahkan budaya negara tersebut dipengaruhi oleh kebudayaan Eropa. Penelitian ini menggunakan metode deskriptif dengan teknik pengumpulan data dengan wawancara terstruktur, data melalui jurnal, dan survey observasi lapangan. Telaah ini menunjukkan baik secara langsung maupun tidak langsung bahwa terdapat pengaruh antara kekuasaan pemerintah era poskolonial (1945-1965) terhadap arsitek Indonesia sekaligus terhadap gaya arsitektur. Telaah ini mengambil lokasi di kota Medan untuk melihat apakah pengaruh pemerintah pusat yang mayoritas proyek pembangunannya berada di pulau Jawa juga ikut mempengaruhi gaya arsitektur di kota Medan. Arsitek yang aktif dalam pembangunan proyek pemerintah pada era poskolonial juga ikut terpengaruh oleh pemerintah dalam mengekspresikan desain atau rancangannya.
\end{abstract}

Kata Kunci: Kekuasaan, Poskolonial, Arsitektur, Medan.

\section{PENDAHULUAN}

Menurut Iskandar (2002), arsitektur adalah produk budaya yang tidak independen. Arsitektur berada pada satu ruang waktu yang dipenuhi oleh berbagai hasrat manusia untuk berkuasa. Arsitektur dapat dijadikan sebuah "identitas" untuk menandakan kekuasaan dan kemampuan sang penguasa. Hal ini dapat terlihat dalam pembangunan piramida di Mesir oleh Firaun Sneferu dan penataan Candi Prambanan yang menyiratkan daerah-daerah taklukan pada pembagian ruangnya (Sopandi, 2013).

Sedangkan pada awalnya, poskolonialisme adalah istilah yang merujuk kepada negara-negara pada periode setelah kemerdekaan. Tetapi, sejak akhir 1970, istilah ini dikaji kembali dan dipergunakan secara luas untuk menandakan pengalaman politik, bahasa, dan budaya dari masyarakat bekas koloni Eropa. Menurut July Hidayat (2004), poskolonialisme merupakan pemikiran tentang diferensi budaya. Poskolonialisme menentang universalisme nilainilai budaya Barat.

Arsitektur dapat menjadi salah satu alat hegemoni pemerintah karena arsitektur adalah produk wacana dan realitas budaya. Dengan demikian ia tidak terlepas dari pengaruh sistem kekuasaan yang berlaku di satu negara.

Situasi poskolonial dalam era Soekarno membuatnya lebih berpaling pada hal-hal besar, kepada gagasan besar tentang kebangsaan dan nasionalitas dibandingkan kepada ekonomi rakyat (Iskandar, 2011). Menurut A. D. King (2009), setelah daerah bekas koloni Eropa merdeka, mereka lebih mengutamakan membangun keadaan politik (atau) ekonomi yang lebih independen.

Citra baru pun dibentuk untuk menggiring bangsa kepada cita-cita Soekarno untuk mengikat dan memberikan arah. Arsitektur pun dibangun untuk menunjukkan citra tersebut. Arsitektur pada era poskolonial ini 
menunjukkan bahwa betapa bangsa yang baru ini mampu membuat sesuatu yang besar, sesuatu yang monumental pada zamannya, sehingga ke sana bangsa ini semestinya dibawa (Iskandar, 2011).

Bersamaan di masa itu, langgam arsitektur yang sedang popular adalah langgam arsitektur modern. Arsitektur modern dapat dicirikan dengan sistem grid modular degan kulit penutup tipis puritan tanpa artikulasi (Siswanto, 1994). Walaupun sebenarnya pada awalnya modernisme adalah gagasan awal untuk merepresentasikan ide sosialisme ke dalam arsitektur seperti yang tertuang dalam La Sarraz Declaration (Iskandar, 2011).

Dalam penelitian ini akan dikaji hubungan baik langsung maupun tidak langsung antara kekuasaan dan arsitektur. Yang menjadi pertanyaan adalah apakah pengaruh kepemimpinan Soekarno di Jawa ikut mempengaruhi gaya arsitektur di tempat lain, khususnya di Kota Medan.

\section{TUJUAN PENELITIAN}

Tujuan dari penelitian ini adalah sebagai berikut:

1. Mengetahui kebijakan pemerintah apa saja yang berpengaruh terhadap arsitektur Indonesia dan kemudian mempengaruhi kota Medan.

2. Mengetahui pengaruh kebijakan politik pemerintah pada era poskolonial di Indonesia terhadap arsitektur di kota Medan.

\section{LANDASAN TEORI}

\section{Pengertian Poskolonial}

Secara etimologis, negara poskolonial adalah sebuah negara bekas kolonialisme. Menurut Aschroft dkk. dalam Hidayat (2004), kolonialisme adalah eksploitasi budaya yang dilakukan Eropa secara spesifik selama lebih dari 400 tahun. Maka, poskolonialisme adalah masa atau waktu sesudah atau pasca era kolonial.

Istilah poskolonialisme tidak hanya merujuk kepada satu ruang waktu tapi juga satu pemahaman. Pemahaman ini didasarkan kepada perubahan kehidupan sosial, ekonomi, politik, dan kebudayaan yang telah diubah oleh masuknya kolonialisme ke dalam negara-negara dunia ketiga.
Menurut Kusno (2006), konteks poskolonial memiliki dua kesadaran yang berkontradiksi. Yang pertama adalah keadaan baru ini menciptakan peluang yang lebih banyak bagi masyarakat. Ia menciptakan kesadaran akan sebuah era yang benar-benar baru dibandingkan era kolonialisme. Di sisi lain, masyarakat bekas kolonial harus berjumpa kembali dengan masa lalunya yang direpresentasikan lewat arsitektur dan perencanaan kawasan yang saling menyilang antara masa lalu dan masa kini.

\section{Keadaan Politik Indonesia pada Era Poskolonial}

Sebagai presiden pertama Republik Indonesia, Soekarno dikenal dengan jiwa pemberontak, hal itu sebenarnya merupakan pengaruh dari perjalanan hidup dan karir politik pada masa itu yang selalu terjerat oleh bangsa asing yang datang dengan sikap imperialisme barat sehingga dalam pandangan Soekarno, setiap bangsa dan negara mempunyai jalan masing-masing dalam menentukan kemana arah dan tujuan bangsa dan negara tersebut, namun jika dalam penentuan arah dan tujuan bangsa dan negara tersebut dihalang halangi, maka sudah sepantasnya bangsa dan negara tersebut melawan dengan kekuatan penuh sebagai respon atas pengaruh itu.

Bagian terpenting dalam sejarah Soekarno dan Indonesia terjadi pada saat Soekarno menerapkan suatu konsepsi tentang Demokrasi Terpimpin. Dalam pandangannya adalah demokrasi Indonesia sejak zaman purbakalamula ialah demokrasi terpimpin, dan ini adalah karakteristik bagi semua demokrasi asli di Benua Asia. Atas dasar itu, Soekarno menerapkan demokrasi terpimpin sehingga mengakibatkan timbulnya suatu sistem otoriter, sebab kekuasaan terpusat dan dengan kekuasaan seperti itu, Soekarno melakukan tindakan nondemokratis, hingga akhirnya Soekarno digulingkan oleh berbagai elemen.

Demokrasi Terpimpin diperkenalkan oleh Soekarno pada 1957. Demokrasi Terpimpin secara tidak langsung adalah sebuah bentuk afirmasi mengenai peraturan personal Soekarno yang mengingatkan kita kepada feodalisme suku Jawa. Secara khususnya, Demokrasi Terpimpin menyebabkan pusat kekuasaan berada pada tangan Soekarno.

Pada era Orde Lama yang berakhir pada tahun 1965, Soekarno memiliki banyak arsitek 
yang sering diperkerjakan pada proyek pemerintahan. Proyek-proyek ini termasuk pembangunan bangunan pemerintahan, stadion, dan patung-patung.

Proyek ini dilatar belakangi oleh keinginan Soekarno dalam membuat Jakarta semakin modern. Ia ingin menaikkan kepercayaan diri bangsa Indonesia yang telah jatuh akibat kolonialisme Eropa. Jakarta yang diubah menjadi sesuatu yang modern mengkomunikasikan identitas baru bangsa Indonesia sebagai suatu negara merdeka.

\section{Kebijakan Pemerintah Soekarno pada Era Poskolonial}

Politik Mercusuar pada dasarnya adalah politik di mana Indonesia menjadi pusat dari negara-negara berkembang. Politik Mercusuar dilaksanakan dengan pembangunan secara besar-besaran tanpa adanya social control. Namun, ternyata pelaksanaan Politik Mercusuar ini mendapat banyak perlawanan dari rakyat.

Tujuan dari Politik Mercusuar itu sendiri adalah:

1. Politik Mercusuar bertujuan menjadikan Jakarta atau Indonesia sebagai mercusuar yang menerangi negara-negara yang sedang berkembang (Nefo).

2. Politik Mercusuar menjadi jembatan untuk mengemukakan gagasan penggalangan kekuatan dari negara-negara yang baru merdeka, negara yang masih memperjuangkan kemerdekaan, negaranegara dari blok sosialis, dan negara-negara yang masih berkembang dalam suatu kelompok bernama The New Emerging Forces (Nefo).

3. Melalui Politik Mercusuar kesenangan Soekarno akan sesuatu yang simbolik dapat terakomodasi ketika ia amat sangat bernafsu menjadi pemimpin Nefo, kebutuhan untuk dihargai dapat terpenuhi dengan munculnya Indonesia sebagai pemimpin yang dihormati di kawasan dan di panggung internasional.

4. Dengan Politik Mercusuar impian Presiden Soekarno untuk membuat proyek-proyek spektakuler akan terwujud. Pembangunan ini tak lain menunjukkan daya saing Indonesia dengan negara-negara lain dan semakin membuat posisi Indonesia di dunia internasional dapat diperhitungkan.
Pada pelaksanaannya, Politik Mercusuar pada Demokrasi Terpimpin 1959-1965 terjadi sebagai berikut:

1. Pelaksanaan Politik Mercusuar diawali dengan membentuk Nefo dan Oldefo yang bertujuan untuk menggolongkan beberapa negara dalam kelompok-kelompok tertentu yaitu Nefo sebagai blok negara komunis dan Oldefo sebagai kelompok negara liberal di mana kemudian Indonesia lebih condong ke kelompok Nefo.

2. Membentuk Conference of The New Emerging Forces (Conefo) untuk membentuk kekuatan baru yang beranggotakan negara-negara berkembang untuk menyaingi kekuatan 2 blok sebelumnya (Uni Soviet dan Amerika).

3. Proyek Mercusuar sebagai tonggak pelaksanaan revolusi fisik karena proyek besar dilaksanakan pada saat itu seperti Hotel Mulia, Stadion Utama Senayan, stasiun TVRI, Gelanggang Olahraga, dan kompleks Conefo yang sekarang adalah gedung MPR/DPR.

4. Pelaksanaan Games of the New Emerging Forces (Ganefo) semacam pesta olahraga atau Olimpiade atau Asian Games. Dasarnya adalah semangat Konferensi Asia-Afrika di Bandung. Tujuannya adalah mempererat hubungan antar negara berkembang. Kesuksesan Ganefo tidak hanya pada bidang olahraga namun juga merambah ke dunia politik.

Pada poin-poin tujuan dan pelaksanaan Proyek Mercusuar di atas terdapat satu sampai tiga poin pada masing-masing pembahasan yang mengaitkan arsitektur dengan kebijakan politik pemerintahan Soekarno, yaitu:

1. Dapat mewujudkan keinginan Soekarno akan sesuatu yang monumental. Monumental pada KBBI artinya bersifat menimbulkan kesan peringatan pada sesuatu yang agung. Dalam menimbulkan kesan yang agung bisa ditampilkan lewat patung, monumen, bangunan arsitektur, dan lain-lain.

2. Proyek Mercusuar menyebabkan keinginan Soekarno untuk membangun proyek spektakuler semakin mungkin terwujud. Contoh proyek spektakuler yang sudah dibangun ada dalam bentuk monumen, hotel, stadion, dan lain-lain. 
3. Pelaksanaan Politik Mercusuar tersebut, terwujudlah pembangunan proyek-proyek besar dan pada puncaknya terlaksana Ganefo sebagai manifestasi Politik Mercusuar.

Proyek Mercusuar Soekarno berkaitan erat dengan kondisi sosial politik Indonesia juga dengan perkembangan arsitektur dunia pada saat itu. Proyek ini dilaksanakan pada tahun 19591965. Pada masa ini, arsitektur yang berkembang adalah langgam arsitektur modern dengan international style-nya. Beberapa bangunan dibangun dengan mencitrakan 'arsitektur yang mencuri perhatian' dengan karakter unik, megah, dan monumental.

Beberapa intisari dari Proyek Mercusuar Soekarno dan hubungannya dengan gaya arsitektur dapat disimpulkan seperti berikut (Kusumawati, 2005):

1. Suatu bangunan apabila menonjolkan struktur yang dimilikinya, berarti bangunan tersebut menampilkan struktur tegak dan datar sehingga bangunan tersebut menjadi kokoh. Selain itu sistem konstruksi juga dapat memberikan kesan monumental pada bangunan dengan menampilkan garis-garis strukturnya.

2. Bentuk bangunan yang dipengaruhi arsitektur modern mengambil bentuk sederhana berupa kotak, balok bukan bentuk yang kesannya dicari-cari. Dari bentuk yang sederhana ini pula dapat dibangun bentuk monumental karena monumental biasanya bersifat sederhana, bersih, dan polos.

3. Skala pada bangunan juga dapat mendukung tercapainya bangunan monumental yaitu dengan skala yang tidak manusiawi. Skala besar dimaksudkan untuk menimbulkan suasana kekuasaan dan berhak mendapat penghormatan. Ekspresi kekuasaan juga dituangkan dalam skala yang tidak manusiawi untuk mengingatkan kita akan kedudukan kita yang lebih rendah dan tidak boleh mengharapkan lebih dari itu.

4. Pemakaian bahan pada suatu bangunan turut mempengaruhi kesan yang ditimbulkan oleh bangunan tersebut. Sebagai bahan penutup marmer akan menyampaikan kesan mewah, kuat, formil, dan agung. Umumnya bahan marmer memang digunakan pada bangunan untuk menunjukkan kemewahan. Beton menampilkan kesan formil, keras, kaku dan kokoh di mana bahan ini biasa digunakan untuk bangunan monumental. Bahan-bahan ini juga merupakan bahan yang awet dan tahan terhadap perubahan cuaca di Indonesia.

5. Dengan memakai sistem grid dan menonjolkan struktur yang dimilikinya, sebuah bangunan akan membentuk irama yang cepat pada deret kolomnya. Irama ini membentuk suatu ketegasan formalitas untuk membentuk ke arah adanya ketegasan dan kekuasaan.

Berdasarkan kriteria di atas dapat kita masukkan ke dalam ciri-ciri bangunan yang memiliki spirit monumental dan dipakai dalam setiap proyek Soekarno dalam menunjukkan Indonesia sebagai negara berkembang baru yang maju. Hal-hal yang menjadi guideline Presiden Soekarno dalam menjalankan Proyek Mercusuar adalah (Kusumawati, 2005):

1. Adanya Pengaruh Arsitektur Modern

Proyek Mercusuar secara keseluruhan lebih menonjolkan langgam arsitektur modern yang memang sedang berkembang pada era tersebut.

2. Arsitektur Monumentalism

Pada zaman tersebut, International Style sedang mengalami sedikit perubahan dengan datangnya arsitektur monumental. Massa yang padat, keras, berat, megah, dan skulptural. Jika sebelumnya didominasi bentuk persegi berubah menjadi lengkungan seperti gedung Conefo. Pada rancangan ruang luar proyek-proyek Mercusuar Soekarno juga menekankan konsep oversize, berbeda dari lingkungannya dan menjadi titik sentral perhatian lingkungan.

Selain itu, tinggi bangunan seringkali sangat menonjol dibandingkan bangunan sekitarnya. Seperti bangunan arsitektur modern, bangunan-bangunan tersebut berusaha tampil berbeda dan menonjol dibandingkan lingkungan sekitarnya.

3. Ekspresi Struktur yang Menonjol

Sistem struktur seringkali berupa grid dengan bagian luar yang menonjolkan beton ekspos. Ekspos strukturnya ditonjolkan untuk menampilkan kesan kokoh, kuat, dan padat.

4. Merespon Iklim Tropis Indonesia

Bangunan pada Proyek Mercusuar juga diusahakan merespon iklim tropis yang 
dimiliki Indonesia. Bahan yang sering digunakan seperti beton dan marmer termasuk tahan terhadap cuaca tropis di Indonesia.

5. Proporsi

Proporsi secara keseluruhan mengikuti proporsi keseluruhan pada waktu itu, didominasi arah vertikal dan horizontal.

\section{METODE PENELITIAN}

Metode penelitian ini menggunakan metode deskriptif dengan pendekatan penelitian kualitatif. Metode deskriptif digunakan untuk mencari unsur-unsur, ciri-ciri, sifat-sifat suatu fenomena. Metode ini dimulai dengan mengumpulkan data, menganalisis data, dan menginterpretasikannya. Metode ini mencoba menggambarkan fenomena-fenomena yang ada, baik yang ada sekarang maupun di masa lampau.

Variabel terikat penelitian ini adalah bangunan umum yang dibangun pada tahun 1945-1965 di kota Medan.

Variabel bebas penelitian ini adalah bangunan umum yang dibangun dengan latar belakang proyek Mercusuar Soekarno dan bangunan umum yang dibangun oleh arsitek kepercayaan Soekarno yang juga ikut memegang proyek Mercusuar di Indonesia.

Dalam mengumpulkan data pada penelitian, digunakan teknik:

1. Wawancara terstruktur

2. Data melalui jurnal, yang berisi sejarah atau analisis mengenai suatu keadaan historis di masa lampau

3. Observasi, mengunjungi sendiri objek sejarah yang berhubungan dengan judul penelitian.

\section{HASIL DAN PEMBAHASAN}

Perkembangan arsitektur poskolonial pada daerah pusat atau kota Jakarta secara langsung maupun tidak langsung memiliki pengaruh dengan arsitektur di kota Medan. Akibat dari perubahan kondisi sosial politik setelah kemerdekaan dan juga politik luar negeri yang masih belum stabil, pembangunan di Indonesia masih terpusat pada kota Jakarta saja. Pengaruh kondisi politik dalam dan luar negeri terhadap arsitektur di Medan tidak dapat dirasakan secara langsung. Pengaruh pemerintahan pusat dapat dirasakan pada karyakarya arsitek terkenal yang sering menerima proyek pemerintahan dari presiden terhadap karya-karyanya. Pengaruh pemerintahan juga dapat dilihat pada jenis proyek pembangunan yang diterapkan di kota Medan.Gaya arsitektur yang beredar pada era 1945-1965 juga dipengaruhi oleh gaya arsitektur yang sedang booming di kota-kota besar dunia yaitu gaya arsitektur modern. Arsitek yang sering dipekerjakan pemerintah pada era ini adalah Frederich Silaban, Liem Bwan Tjie, Suyudi, Suhamir, dan lain-lain. Karya-karya mereka secara langsung maupun tidak langsung dipengaruhi oleh langgam arsitektur modern. Selain itu, karya-karya mereka juga menunjukkan kondisi sosial politik di Indonesia yang sedang dalam tahap menunjukkan citra dan identitas bangsa. Pengaruh keadaan pemerintahan secara tidak langsung ikut mempengaruhi keputusan arsitek dalam merancang.

Berikut adalah bangunan yang dirancang pada era poskolonial:

\section{Stadion Teladan}

Stadion Teladan terletak di Jalan Stadion, Kec. Medan Barat, kota Medan (Gambar 1-7). Didesain oleh Liem Bwan Tjie dan dibangun pada tahun 1953. Kapasitas penonton sebesar 200.000 orang. Stadion ini terkenal telah menjadi tempat latihan bertahun-tahun klub sepak bola kota Medan, PSMS. Stadion Teladan dibangun pada tahun 1953-1955 dan dirancang oleh arsitek Indonesia keturunan Tionghoa, Liem Bwan Tjie. Beliau adalah salah satu arsitek modern generasi pertama di Indonesia.

Tujuan dibangunnya Stadion Teladan adalah untuk acara Pekan Olahraga Nasional (PON) yang ketiga dan pembukaannya diresmikan langsung oleh Presiden Soekarno. Pada acara pembukaan PON tersebut, Presiden Soekarno menyampaikan pesan-pesan kepada generasi penerus bangsa.

Pekan Olahraga Nasional (PON) diadakan setiap 4 tahun sekali dan merupakan perwujudan dari bangsa Indonesia untuk melakukan pembangunan seutuhnya. Dalam mengadakan PON, peserta dari seluruh provinsi di Indonesia terlibat. Sehingga, hal ini memegang peranan penting dalam menyatukan persatuan dan 
kesatuan bangsa. Kemudian, prestasi yang diperoleh dalam pekan olahraga ini bisa mengangkat harkat martabat masyarakat Indonesia di mata pihak asing.

Hal ini sejalan dengan keinginan Soekarno yang ingin menjadikan Indonesia sebagai negara baru yang disegani negara asing. Apabila Ganefo adalah pekan olahraga se-Asia Pasifik, PON adalah perwujudan pekan olahraga untuk bangsa Indonesia. Fungsinya juga samasama untuk menyatukan masyarakat yang berbeda-beda budaya menjadi memiliki rasa persatuan.

Stadion Teladan Medan sudah banyak mengalami perubahan dibandingkan pada saat pertama kali dibangun. Renovasi seperti penambahan atap pada tribun, kemudian fasad bangunan yang ditambah keramik dan penambahan ruangan juga dilakukan sekitar tahun 2012. Menara pada Stadion Teladan dulunya digunakan untuk menyimpan tangki air untuk keperluan sanitasi sekarang tidak digunakan lagi dan sudah terabaikan. Stadion Teladan sudah memiliki standard nasional, namun semenjak PSSI dibekukan pertandingan bola nasional belum pernah lagi dilakukan di stadion ini. Pertandingan yang sering diadakan di Stadion Teladan saat ini hanya berupa pertandingan daerah.

Pemakaian bahan bangunan yang sudah pabrikasi, bahan bangunan dari bata dan kaca, dan bentuk-bentuk grid tanpa ornamen menyatakan kedekatan bangunan tersebut dengan langgam arsitektur modern. Sayangnya, tampak Stadion Teladan Medan sekarang sudah berubah karena telah mengalami banyak renovasi.

Pada gambar bangunan lama terdapat elemen horizontal dan vertikal yang seperti ditonjolkan untuk menunjukkan estetika bangunan.

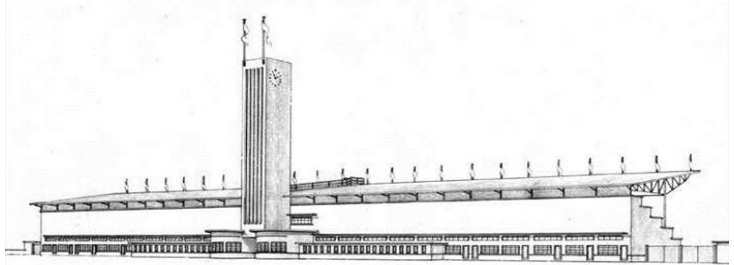

Gambar 1. Sketsa Awal Stadion Teladan

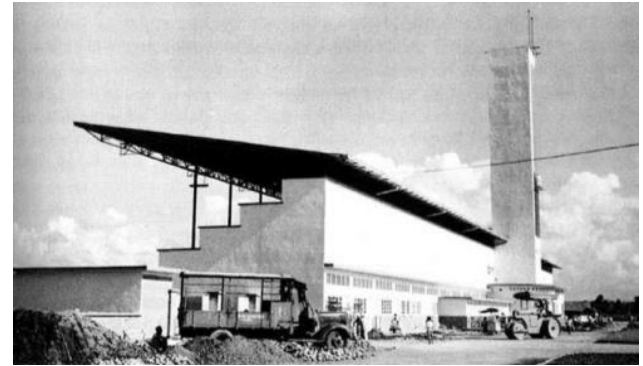

Gambar 2. Perspektif Samping Stadion Teladan pada Awal Pembukaan

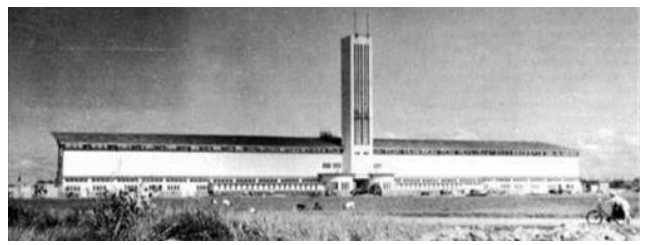

Gambar 3. Tampak Depan Stadion Teladan Lama

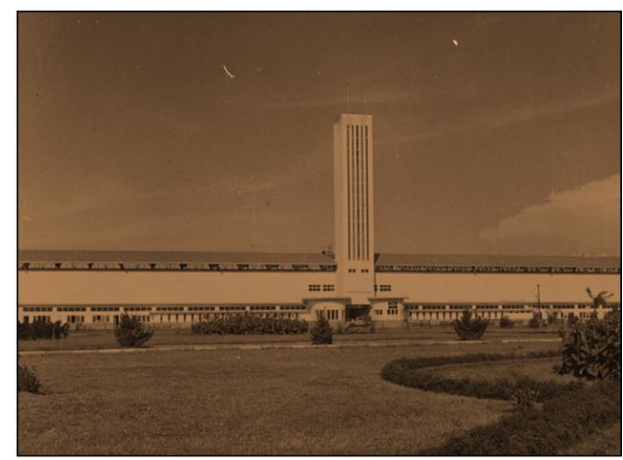

Gambar 4. Foto Lama Stadion Teladan Medan

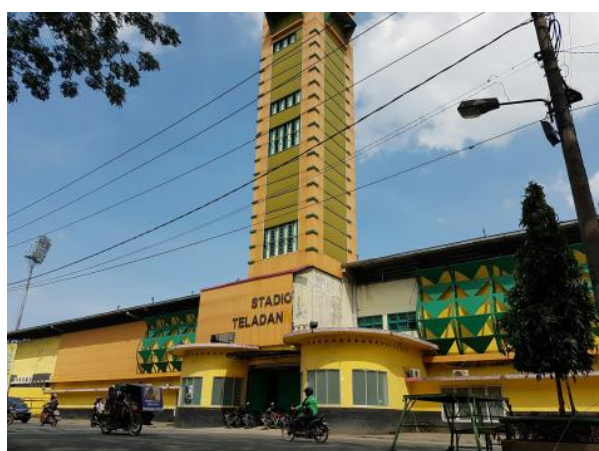

Gambar 5. Kondisi Stadion Teladan Medan pada 2017

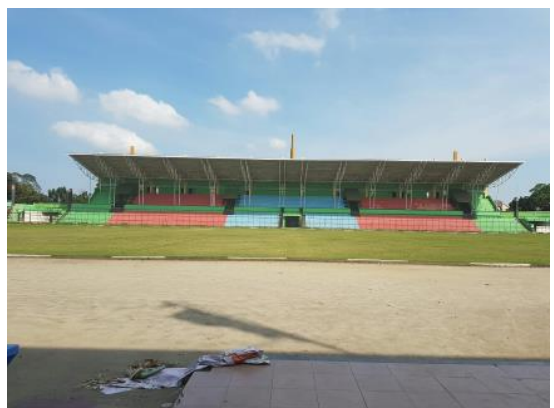

Gambar 6. Kondisi Tribun Stadion Teladan Medan yang Direnovasi dengan Menambahkan Atap 


\section{Universitas HKBP Nommensen}

Universitas HKBP Nommensen dibangun akibat dari semakin banyaknya kebutuhan akan perguruan tinggi bagi lulusan-lulusan Sekolah Menengah Atas (Gambar 7-11). Pada tahun 1952, sudah ada universitas di kota Medan yang dibangun, yaitu USU dan UISU. Namun, daya tampung kedua universitas masih terbatas dan jurusan yang ditawarkan juga tidak banyak. Oleh karena permasalahan inilah, tokoh-tokoh gereja HKBP berinisiatif untuk mendirikan sebuah kampus.

Arsitek Universitas HKBP Nommensen, F. Silaban adalah salah satu arsitek era modern Indonesia dengan ciri khasnya yang menonjolkan elemen struktur vertikal dan horizontal. Balok dan kisi-kisi yang pada tempatnya, tidak adanya ornamentasi, dan pemakaian bahan bangunan pabrikasi adalah salah satu ciri arsitektur modern yang juga merupakan ciri khas dari bangunan F. Silaban itu sendiri. Langgam arsitektur modern berpadu dengan iklim tropis.

Aspek elemen vertikal dan horizontal pada bangunan kampus HKBP Nommensen sangat kelihatan. Elemen vertikal pada bangunan merupakan kolom-kolom yang menyangga bangunan sedangkan elemen horizontal dapat dilihat pada balok dan overstek yang kelihatan.

Fasad bangunan tidak memiliki ornamen dan bangunan diberi warna senada. Bentuk bangunan persegi empat sederhana. Sekilas tampilan depan kampus HKBP Nommensen seperti fasad Masjid Istiqlal. Kolom-kolom dan overstek yang panjang menjadi elemen modern namun disesuaikan dengan iklim tropis Indonesia.

Kampus Universitas HKBP Nommensen tidak banyak diubah secara fisik. Dinding tetap mempertahankan warna aslinya yang tidak dicat dan menggunakan bata exposed. Ekspresi struktur tampak jelas pada deretan kolom dan balok serta kantilever yang menaungi kampus ini. Kisi-kisi juga adalah bagian dari konstruksi dan bukan tambahan pada bangunan. Perubahan yang tampak hanya pada penambahan pendingin ruangan atau AC sehingga pada beberapa ruangan kisi-kisi ditutup. Sayangnya pada lorong antar ruangan menjadi gelap karena tertutup ruangan di sisi kiri dan kanannya.

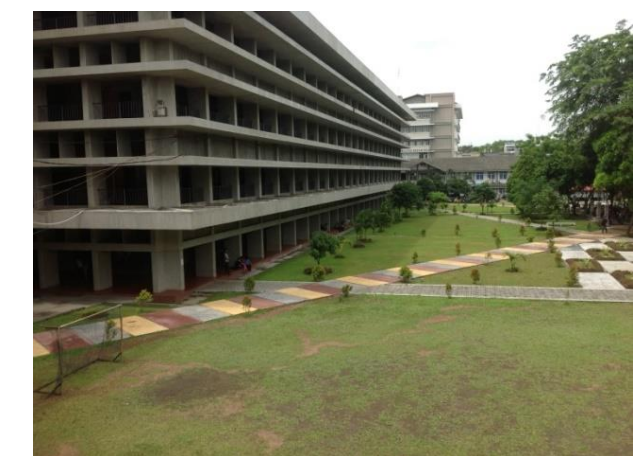

Gambar 7. Foto perspektif Universitas HKBP Nommensen

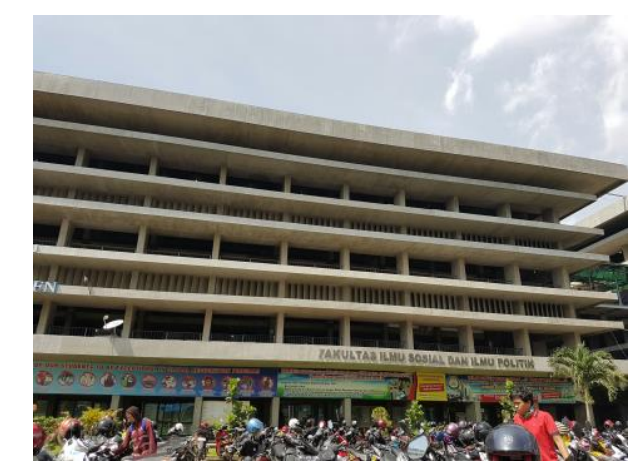

Gambar 8. Tampak Depan Universitas HKBP Nommensen

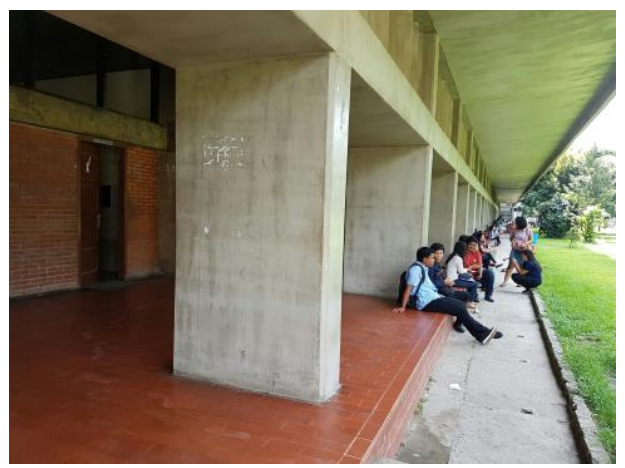

Gambar 9. Selasar Universitas HKBP Nommensen dengan Rancangan Kantilever yang Panjang untuk Pembayangan

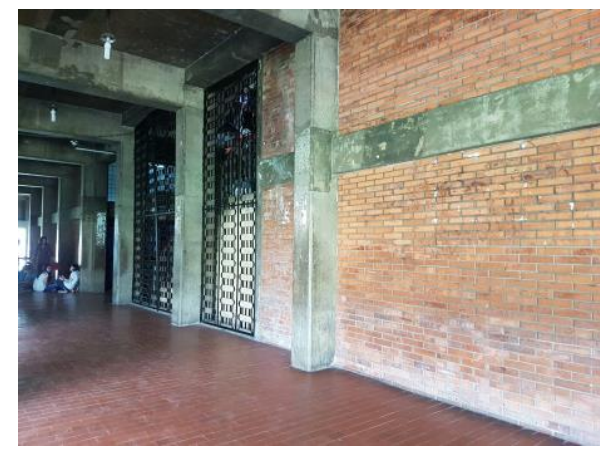

Gambar 10. Ekspresi Arsitektur yang Jujur dengan Penggunaan Bata dan Beton Ekspos 


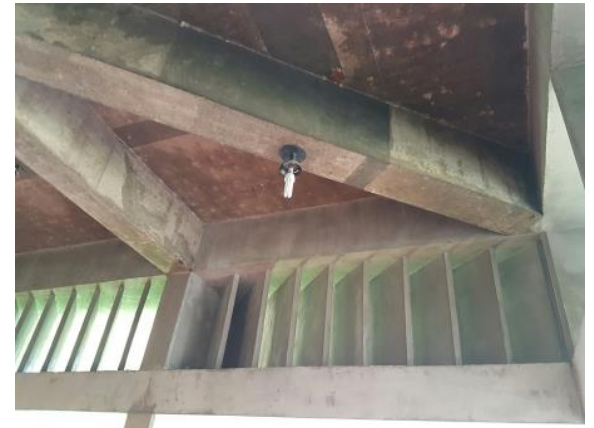

Gambar 11. Ekspresi Arsitektur yang Jujur dengan Menggabungkan Kisi-kisi Menjadi Bagian dari Konstruksi Bangunan

\section{Bank BNI 1946 Medan}

Bank Negara Indonesia (BNI) didirikan pada tanggal 5 Juli 1946 dan menjadi bank pertama milik negara yang didirikan setelah kemerdekaan. BNI sempat berfungsi menjadi bank sentral dan bank umum sebagaimana tertuang dalam Peraturan Pemerintah Pengganti Undang-undang No. 2/1946 sebelum akhirnya beroperasi menjadi bank komersial setelah tahun 1955.

Bank BNI 1946 Jl. Pemuda dibangun oleh arsitek F. Silaban pada 1962 dan telah mengalami banyak perubahan. Bangunan asli telah ditambahkan beberapa lantai ke atas dan fasad ditutupi oleh ACV karena pemakaian AC di dalam. Yang masih terlihat pada fasad adalah kolom-kolom sejajar yang menjadi ciri khas bangunan F. Silaban (Gambar 12).

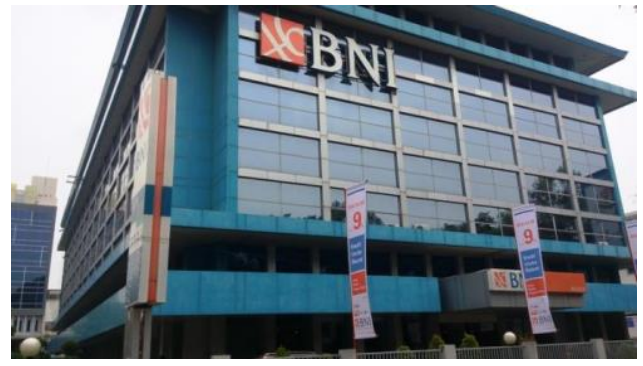

Gambar 12. Kondisi Bank BNI 1946 Medan di Jl. Pemuda

Kebijakan atau pengaruh pemerintah atau pemerintahan yang ikut mempengaruhi arsitektur di Medan antara lain:

1. Pekan Olahraga Nasional

Pekan Olahraga Nasional (PON) adalah kompetisi olahraga yang diadakan setiap 4 tahun sekali dan dimulai sejak tahun 1948. Ajang olahraga ini dibentuk dengan latar belakang keinginan untuk mempertemukan bangsa Indonesia dari berbagai daerah dengan latar belakang budaya yang berbeda untuk bersatu dan merasa memiliki satu bangsa dan nasionalisme.

2. Adanya kebutuhan akan lulusan perguruan tinggi di Indonesia.

3. Adanya kebutuhan akan perbaikan perekonomian dan perbankan di Medan.

Tabel 1, 2, dan 3 menjelaskan tentang data bangunan, latar belakang bangunan, dan perbandingan langgam arsitektur modern terhadap bangunan.

Tabel 1. Tabel Data Bangunan

\begin{tabular}{|l|c|l|l|}
\hline \multicolumn{1}{|c|}{ Bangunan } & Tahun & \multicolumn{1}{c|}{ Arsitek } & \multicolumn{1}{c|}{ Langgam Arsitektur } \\
\hline Stadion Teladan Medan & 1953 & Liem Bwan Tjie & Arsitektur Modern \\
\hline Universitas HKBP Nommensen Medan & 1982 & Frederich Silaban & Arsitektur Modern Tropis \\
\hline Bank BNI 1946 Medan & 1962 & Frederich Silaban & Arsitektur Modern \\
\hline
\end{tabular}

Tabel 2. Tabel Latar Belakang Berdirinya Bangunan

\begin{tabular}{|c|c|}
\hline Bangunan & Latar Belakang Pembangunan \\
\hline Stadion Teladan Medan & Dalam rangka Pekan Olahraga Nasional di kota Medan \\
\hline Universitas HKBP Nommensen Medan & $\begin{array}{c}\text { Kebutuhan akan adanya universitas dan lulusan perguruan } \\
\text { tinggi yang diinisiasi oleh ephorus HKBP }\end{array}$ \\
\hline Bank BNI 1946 Medan & Kebutuhan akan layanan perbankan di kota Medan \\
\hline
\end{tabular}

Tabel 3. Tabel Perbandingan Langgam Arsitektur Modern terhadap Bangunan

\begin{tabular}{|l|c|c|c|}
\hline \multicolumn{1}{|c|}{ Ciri Arsitektur Modern } & Stadion Teladan & $\begin{array}{c}\text { Universitas HKBP } \\
\text { Nommensen }\end{array}$ & $\begin{array}{c}\text { Gedung BNI 1946 } \\
\text { Medan }\end{array}$ \\
\hline Bahan dan material fungsional & $\checkmark$ & $\checkmark$ & $\checkmark$ \\
\hline Estetika mesin & - & - & $\checkmark$ \\
\hline Anti ornamentasi & $\checkmark$ & $\checkmark$ & $\checkmark$ \\
\hline Elemen vertikal & $\checkmark$ & $\checkmark$ & $\checkmark$ \\
\hline Elemen horizontal & $\checkmark$ & $\checkmark$ & $\checkmark$ \\
\hline Bentuk simple & $\checkmark$ & $\checkmark$ & $\checkmark$ \\
\hline Ekspresi terhadap struktur & - & $\checkmark$ & - \\
\hline Bentuk mengikuti fungsi & - & $\checkmark$ & \\
\hline
\end{tabular}




\section{KESIMPULAN}

Arsitektur adalah salah satu cerminan budaya masyarakat. Kebutuhan manusia akan rumah sebagai tempat berlindung disesuaikan dengan kegiatan mereka sehari-hari. Dari sinilah studi antropometri berawal. Namun, fungsi arsitektur tidak hanya ditemui sebagai tempat bernaung di dalam rumah saja tetapi juga sebagai sebuah karya penentu keberhasilan suatu kerajaan, rezim pemerintahan, dan kekuasaan si pemilik. Hal ini sudah dapat ditemui sejak zaman Mesir dengan dibangunnya piramida dan zaman kerajaan Hindu-Buddha dengan pembangunan candi-candi.

Sedangkan poskolonial secara etimologis adalah sebuah era pasca kolonialisme Eropa. Secara studi yang lebih luas, poskolonial dapat juga berarti sebuah keadaan masyarakat yang kondisi sosial, politik, ekonomi, dan budayanya telah dimasuki oleh budaya Eropa. Sehingga kebudayaan awal mereka membaur dan dipengaruhi oleh kebudayaan Eropa tersebut.

Begitu pula dengan arsitektur. Arsitektur sebagai produk budaya juga ikut dipengaruhi oleh kondisi di atas. Kebudayaan Eropa yang masuk pada era kolonial terasimilasi dengan budaya daerah Nusantara untuk kemudian dituangkan ke dalam karya arsitektur. Kemudian karya arsitektur tersebut pun diasosiasikan dengan kekuasaan pemerintah pada zamannya sebagai penanda kebesaran kekuasaan dan kemampuan mereka dibandingkan dengan kekuasaan negara lain.

Kekuasaan pada era poskolonial Soekarno (1945-1965) adalah demokrasi terpimpin di mana kebijakan berpusat pada Beliau. Kebijakannya pun mempengaruhi pembangunan di Medan dan kebijakannya juga bisa mempengaruhi karya seorang arsitek dalam merancang rancangannya. Hal ini dapat dilihat secara langsung maupun tidak langsung pada ketiga bangunan di kota Medan yang dibangun oleh Liem Bwan Tjie dan F. Silaban. Walaupun tidak sepenuhnya karya mereka dipengaruhi oleh kekuasaan pemerintah.

\section{Daftar Pustaka}

Handinoto (2004) Liem Bwan Tjie Arsitek Modern Generasi Pertama Indonesia, Dimensi Teknik Arsitektur, 32 (2), 119130.

Hidayat, July (2004) Desain dalam Konteks Poskolonial. $2 d 3 d: 86-97$.

Iskandar, Barliana M. S. (2002) Relasi Kekuasaan dan Arsitektur: Dari Dekonstruksi ke Sustainable City, Dimensi Teknik Arsitektur, 30 (1), 39-45.

Iskandar, Barliana M. S. (2011) Arsitektur, Kekuasaan, dan Nasionalitas, Bandung: Kerjasama Metatekstur dengan Laboratorium Sejarah Arsitektur, Kota \& Bermukim, Jurusan Pendidikan Arsitektur, Universitas Pendidikan Indonesia.

King, A. D. (2009) Postcolonial Cities. Binghamton: State University of New York Binghamton, 1-6.

Kusno, Abidin (2000) Behind the Postcolonial: Architecture, Urban Space, and Political Cultures in Indonesia, New York: Routledge.

Kusumawati, Bety Dwi (2005) Museum Soekarno di Blitar dengan Langgam Arsitektur pada Era Soekarno. Surakarta: Universitas Sebelas Maret.

Marwati, Annisa (2012) Soekarno dan Soeharto dalam Arsitektur. Depok: Universitas Indonesia.

Siswanto, Andi (1994) Menyangkal Totalitas dan Fungsionalisme: Postmodernisme dalam Arsitektur dan Desain Kota, Jakarta: Jurnal Kalam, Yayasan Kalam.

Sopandi, Setiadi (2013) Sejarah Arsitektur: Sebuah Pengantar, Jakarta: Gramedia Pustaka Utama.

Suzana, Neti (2016) Pelaksanaan Politik Mercusuar di Indonesia pada Masa Demokrasi Terpimpin Tahun 1959-1965. Lampung: Universitas Bandar Lampung. 